\title{
The Performance Analysis of a Fettling Shop Using Simulation
}

\author{
Mathew Thomas \\ Department of Mechanical Engineering, Viswajyothi College of Engineering and Technology, Vazhakulam, \\ Muvattupuzha, Kerala, India.
}

\begin{abstract}
Fettling shop is the product finishing shop of casting products.After the knockout, the casting is taken to the fettling shop for doing the fettling work. The fettling process includes cutting, shot blasting, grinding and painting. In all these process the sand and extra metal on the castings are removed. The project titled 'The performance analysis of a fettling shop using simulation' is based on a fettling shop of a casting industry. The main aim of the project is the performance analysis of the fettling shop. This project is a simulation based project and is done using a simulation tool called arena. The main concepts related with the performance analysis are Bottleneck analysis, Productivity analysis and System improvement analysis.
\end{abstract}

Keywords: Performance analysis, Fettling shop, Bottleneck, Simulation.

\section{Introduction}

The performance analysis is mainly done with Bottleneck analysis, Productivity analysis and System improvement analysis. Here, performance analysis of the fettling shop is done using a simulation tool called arena.

\section{A. PERFORMANCE ANALYSIS}

Performance analysis is the process of analyzing the performance of a system or a process. Here, performance analysis of a casting industry fettling shop is done. The different performance analysis tools are Bottleneck analysis, Productivity analysis and System improvement analysis. The main aim of the project is the performance analysis of the fettling shop. This is a simulation based project and is done using a simulation tool called arena.

\section{B. FETTLING SHOP}

The fettling shop is the product finishing shop of casting products.After the knockout, the casting is taken to the fettling shop for doing the fettling work. The fettling process includes cutting, shot blasting, grinding and painting. In all these process the sand and extra metal on the castings are removed.

\section{BOTTLENECK}

In engineering, a bottleneck is a phenomenon by which the performance or capacity of an entire system is severely limited by a single component. Formally, a bottleneck lies on a system's critical path and provides the lowest throughput. As such, system designers will try to avoid bottlenecks and direct effort towards locating and tuning existing bottlenecks.

\section{PRODUCTIVITY}

Productivity is an average measure of the efficiency of production. Productivity is a ratio of production output to input (i.e, capital, labor, land, materials, etc.). It is a measure of how well the resources are utilized to produce an output. i.e, Productivity=Output/Input. The measure of productivity is defined as a total output per one unit of a total input.

\section{E.SYSTEM IMPROVEMENT}

System improvement is the process of improving the overall performance of the system. The results of system improvement are output maximization, production capacity improvement of the system, reduction of waiting times, reduction of number of products waiting at workstations etc.

\section{F.SIMULATION MODELING}

Simulation modeling is the process of creating and analyzing a digital prototype of a physical model to predict its performance in the real world. Simulation modeling allows designers and engineers to avoid repeated building of multiple physical prototypes to analyze designs for new or existing parts. 


\section{G. BASIC PROCESS ARENA MODULES}

The main basic process arena modules are shown below in table 1 . These basic process arena modules are used for modeling purposes

\begin{tabular}{|c|c|c|l|}
\hline Module Name & Symbol & Function \\
\hline Create & Create & Used as a source to generates new entities. \\
\hline Assign & - Assign & Used to assign values to variables \\
\hline Process & - & Process & Used as the main processing method \\
\hline Record & - & Record & Used to collect statistics in a particular location in the model \\
\hline Dispose & - & Dispose & Used as the exit point of entities from a simulation model \\
\hline
\end{tabular}

Table 1-Basic process arena modules

\section{H. ADVANCED TRANSFER MODULES}

The advanced transfer modules used for modeling process are request, transport, station and free. Symbols \& functions of advanced transfer modules are shown in table 2

\begin{tabular}{|c|c|c|l|}
\hline Module Name & Symbol & Function \\
\hline Request & Request & $\begin{array}{l}\text { Used to assign a transporter unit to an entity and then to move the } \\
\text { unit to the entity's location }\end{array}$ \\
\hline Transport & - & Transport & $\begin{array}{l}\text { Used to transfer an entity controlling a transporter unit to a } \\
\text { destination. }\end{array}$ \\
\hline Station & - & Station & Used to define a station or a set of stations. \\
\hline Free & - Free & Used to release the entity's most recently allocated transporter unit. \\
\hline
\end{tabular}

Table 2-Advanced transfer modules

\section{Literature Review}

Timothy M. Elftman (1999) described about the examination of the effects of bottlenecks and production control rules at assembly stations. In manufacturing centers, products manufactured at different locations are often joined together at assembly stations. If not managed properly this common event can lead to defective products, lost throughput, and increased WIP. All of which will result in lost capital for the manufacturing center. Christoph Roser et.al (2002) suggested various techniques for shifting bottleneck detection. This involves a novel method for detecting bottlenecks in manufacturing systems and the shifting of these bottlenecks. All manufacturing systems are constrained by one or more bottlenecks. Improving the bottleneck will improve the whole system.

Karthik Krishna et.al (2008) described the iterative use of simulation and scheduling methodologies to improve productivity. It includes the integrated use of process simulation, production scheduling, and detailed analysis of material-handling methods and their improvement. The study undertook the identification and improvement of production and scheduling policies to the benefit of a manufacturing process whose original throughput capacity fell significantly short of high and increasing demand. Prameth tantivanich et.al (2002) suggested a simulation approach for productivity improvement of an IC factory. It is used to develop a simulation model to intimate a real world IC assembly line in order to identify alternatives for productivity improvement. Melaka (2009) described productivity analysis of table top fan assembly process using arena simulation. The objectives of this study are mainly to investigate the problems and wastes in the assembly process of table top fan and simulate the processes for higher productivity and efficiency. There are some significant problems faced in the assembly processes such as bottleneck at some operation and low productivity and efficiency. 


\section{Methodology And Analysis}

The main aim of the project is the performance analysis of the fettling shop. The fettling shop is the product finishing shop of casting products. The methodology of the project is shown below.

\begin{tabular}{|c|}
\hline IDENTIFICATION OF VARIABLES \& PERFORMANCE MEASURES \\
\hline DATA COLLECTION \\
\hline MODELING \& SIMULATION OF THE CURRENT SYSTEM \\
\hline PERFORMANCE ANALYSIS \\
\hline \multicolumn{1}{|c|}{} \\
\hline MPPLYINING PERFORMANCE IMPROVEMENT SUGGESTIONS \\
\hline PERELLING \&SIMULATION OF THE NEW SYSTEM \\
\hline \\
\hline
\end{tabular}

Figure 1-Methodology

\section{ANALYSIS \\ The different cases in the analysis are described below.}

1. Analysis of the system performance with respect to number of machines.

The overall performance of the system can be improved by increasing the number of machines in workstations.

2. Analysis of the system performance with respect to transporters.

The overall performance of the system can be improved by increasing the number of transporters in fettling shop.

3. Analysis of the system performance with respect to distance between workstations.

Smaller distance helps for reducing material handling time and maximizing the products output. Distance between workstations is an important variable which affects the overall performance.

4. Analysis of the system performance with respect to sequence.

Change the processing sequence of products for achieving more products output and maximum system performance.

5. Analysis of the system performance with respect to product mix.

We can change the product mix by increasing the number of products from present condition. It helps to achieve more product variety from the fettling shop.

\section{Results}

The results of different simulation experiments are as follows.

A. Analysis Of The System Performance With Respect To Number Of Machines.

a) Output

\begin{tabular}{|l|l|}
\hline Average number of casting products finished in a week (7 & 332
\end{tabular}

Days)

b) Delay Times in Fettling Shop

\begin{tabular}{|l|l|}
\hline Average delay of products in a week & 84.61 minutes (1.41 hours) \\
\hline
\end{tabular}

c) Utilization of Machines in Fettling Shop

\begin{tabular}{|l|l|}
\hline Utilization of cutting machines & $22 \%$ \\
\hline Utilization of grinding machines & $58 \%$ \\
\hline Utilization of painting machine & $37 \%$ \\
\hline Utilization of shot blasting machine & $21 \%$ \\
\hline
\end{tabular}

\section{d) Flow Times of Products}

\begin{tabular}{|l|l|}
\hline Average cylinder frame flow time & 296.36 minutes \\
\hline Average fly wheel 1 flow time & 243.86 minutes \\
\hline Average fly wheel 2 flow time & 135.05 minutes \\
\hline Average fly wheel 3 flow time & 119.21 minutes \\
\hline Average gear case flow time & 137.82 minutes \\
\hline Average machine tool bed flow time & 275.40 minutes \\
\hline
\end{tabular}

\section{e) Total Time}

Average total time of fettling shop is 218.54 minutes (3.642 hours) 


\section{B. ANALYSIS OF THE SYSTEM PERFORMANCE WITH RESPECT TO TRANSPORTERS}

\section{a) Output}

Average number of casting products finished in a

week (7 Days)

b) Delay Times in Fettling Shop

Average delay of products in a week

\section{c) Utilization of Machines in Fettling Shop}

\begin{tabular}{|l|c|}
\hline Utilization of cutting machines & $30 \%$ \\
\hline Utilization of grinding machines & $86 \%$ \\
\hline Utilization of painting machine & $73 \%$ \\
\hline Utilization of shot blasting machine & $28 \%$ \\
\hline
\end{tabular}

\section{d) Flow Times of Products}

\begin{tabular}{|l|l|}
\hline Average cylinder frame flow time & 387.27 minutes \\
\hline Average fly wheel 1 flow time & 331.37 minutes \\
\hline Average fly wheel 2 flow time & 195.71 minutes \\
\hline Average fly wheel 3 flow time & 149.73 minutes \\
\hline Average gear case flow time & 168.45 minutes \\
\hline Average machine tool bed flow time & 359.24 minutes \\
\hline
\end{tabular}

\section{e) Total Time}

Average total time $=288.63$ minutes ( 4.81 hours)

\section{ANALYSIS OF THE SYSTEM PERFORMANCE WITH RESPECT TO DISTANCE BETWEEN WORKSTATIONS.}

\section{a) Output}

Average number of casting products finished in a

week (7 Days)

b) Delay Times in Fettling Shop

Average delay of products in a week

\section{c) Utilization of Machines in Fettling Shop}

\begin{tabular}{|l|l|}
\hline Utilization of cutting machines & $30 \%$ \\
\hline Utilization of grinding machines & $86 \%$ \\
\hline Utilization of painting machine & $73 \%$ \\
\hline Utilization of shot blasting machine & $28 \%$ \\
\hline
\end{tabular}

\section{d) Flow Times of Products}

\begin{tabular}{|l|l|}
\hline Average cylinder frame flow time & 390.10 minutes \\
\hline Average fly wheel 1 flow time & 329.41 minutes \\
\hline Average fly wheel 2 flow time & 195.51 minutes \\
\hline Average fly wheel 3 flow time & 149.17 minutes \\
\hline Average gear case flow time & 170.38 minutes \\
\hline Average machine tool bed flow time & 364.80 minutes \\
\hline
\end{tabular}

\section{e) Total Time}

Average total time $=289.58$ minutes $(4.82$ hours $)$

\section{ANALYSIS OF THE SYSTEM PERFORMANCE WITH RESPECT TO SEQUENCE.}

\section{a) Output}

$$
\text { Average number of casting products finished in a }
$$

week (7 Days)

\section{b) Delay Times in Fettling Shop}

Average delay of products in a week

c) Utilization of Machines in Fettling Shop

\begin{tabular}{|l|c|}
\hline Utilization of cutting machines & $44 \%$ \\
\hline Utilization of grinding machines & $96 \%$ \\
\hline Utilization of painting machine & $64 \%$ \\
\hline Utilization of shot blasting machine & $27 \%$ \\
\hline
\end{tabular}

d) Flow Times of Products

Average cylinder frame flow time

Average fly wheel 1 flow time 
The Performance Analysis Of A Fettling Shop Using Simulation

\begin{tabular}{|l|l|}
\hline Average fly wheel 2 flow time & 423.63 minutes \\
\hline Average fly wheel 3 flow time & 412.70 minutes \\
\hline Average gear case flow time & 406.60 minutes \\
\hline Average machine tool bed flow time & 408.96 minutes \\
\hline
\end{tabular}

e) Total Time

Average total time $=415.30$ minutes $(6.92$ hours $)$

E.ANALYSIS OF THE SYSTEM PERFORMANCE WITH RESPECT TO PRODUCT MIX.

a) Output

Average number of casting products finished in a

week (7 Days)

b) Delay Times in Fettling Shop

\begin{tabular}{|l|l|}
\hline Average delay of products in a week & 149.30 minutes (2.48 hours) \\
\hline
\end{tabular}

c) Utilization of Machines in Fettling Shop

\begin{tabular}{|l|l|}
\hline Utilization of cutting machines & $26 \%$ \\
\hline Utilization of grinding machines & $85 \%$ \\
\hline Utilization of painting machine & $71 \%$ \\
\hline Utilization of shot blasting machine & $26 \%$ \\
\hline
\end{tabular}

d) Flow Times of Products

\begin{tabular}{|l|l|}
\hline Average cylinder frame flow time & 153.99 minutes \\
\hline Average fly wheel 1 flow time & 341.66 minutes \\
\hline Average fly wheel 2 flow time & 349.01 minutes \\
\hline Average fly wheel 3 flow time & 181.47 minutes \\
\hline Average gear case flow time & 404.46 minutes \\
\hline Average machine tool bed flow time & 178.10 minutes \\
\hline Average 7-th product flow time & 366.94 minutes \\
\hline
\end{tabular}

\section{e) Total Time}

Average total time $=276.77$ minutes (4.61hours)

\section{Conclusion}

The various satisfied results of the project are as follows. The project helped to understand the current state and performance of the fettling shop. Arena modeling helped to understand critical areas like bottleneck. Simulation study on the model helped to identify the improvement areas of the current system. 'What if analysis' helped to forecast expected future results after new system improvement suggestions. Finally, the performance improvement model is obtained.

\section{References}

[1] Al.Araidah, O.Boran (2012) - "Reducing delay in healthcare delivery at outpatients clinics using discrete event simulation".

[2] Bronislav Chramcov, Petr beran (2005) - "A simulation approach to achieving more efficient production systems".

[3] Chompoonoot kasemset,Voratas kachitvichyanukul (2008)- "Simulation-based procedure for implementing theory of constraints: extension for cases with multiple bottlenecks".

[4] Christoph Roser,Masaru Nakano ,Minoru Tanaka (2002) - "Shifting bottleneck detection”.

[5] Felipe f. Baesler,Milton Moraga,Francisco j. Ramis (2002) - "Productivity improvement in the wood industry using simulation and artificial intelligence".

[6] Galina Merkuryeva (2005) - "Metamodelling for simulation applications in production".

[7] Julian h. Kang,Sung-mo ahn, Ji-hyun nam (2006)- "Productivity assessment of rock transportation trucks using simulation technology".

[8] Kidak Levent B,Aksarayli Mehmet (2011) - "Simulation modeling for process improvement in a general surgery service”.

[9] Melaka (2009)- "Productivity analysis of table top fan assembly process using arena simulation".

[10] Navin Gupta, Edward j. Williams (2005) - "Simulation improves service and profitability of an automobile service garage".

[11] Seraj yousef abed (2004) -"'A simulation study to increase the capacity of a rusk production line ".

[12] Prameth tantivanich (2002), Prapaisrisudasna- "A simulation approach for productivity improvement of an ic factory". 